\title{
ANALISIS POLA KONSUMSI DAN FAKTOR-FAKTOR YANG MEMPENGARUHI PENGELUARAN KONSUMSI PANGAN POKOK RUMAHTANGGA DI PROVINSI RIAU
}

\section{Analysis of Consumption Pattern and the Factors Influence the Household's Expenditures in Food Consumption in Riau Province}

\author{
Heriyanto \\ Fakultas Pertanian Universitas Islam Riau. Jl. Kaharuddin Nasution 113, Pekanbaru 28284 Riau \\ Telp. : 0761-72126 ext. 123, Fax : 0761-674681 \\ (Diterima: November 2016; Disetujui: Maret 2017)
}

\begin{abstract}
This study aimed to analyze the food consumption pattern of households by income level and education, to analyze the factors affecting the dominant staple food consumption expenditure of households, and to analyze the response of trees to food expenditure dominant factors that influence it. For research purposes constructed model Almost Ideal Demand System (AIDS), with Seemingly Unrelated Regression (SUR) method. The food commodities included in the model comprised of seven primary commodities. rice and sago, milk, beef and chicken, salt, sugar, cooking oil, as well as vegetables and fruits. The results showed that at a higher level of income, the proportion of food expenditure to others tends to decrease. The higher the housewives education's level, the higher the consumption of dairy, beef and chicken, vegetables and fruits, while the consumption of rice and sago, sugar, and cooking oil tends to decline. Most of the parameter estimates of commodity prices and household income level of dominant influence consumption for each commodity group. Price's elasticity of all commodities tends to be negative and not responsive to the price changes. Similarly, cross elasticities showed the consumption expenditure of each commodity is not responsive to changes in other commodity prices. However, according to its income elasticity, four commodities (beef and chicken, as well as vegetables and fruits), are responsive to changes in income. From these findings, it can be stated that the policies related to the efforts to increase revenues performed better than price control policy. The efforts to improve household income is important to increase consumption, particularly the consumption of beef and chicken, as well as vegetables and fruits.
\end{abstract}

Keywords: Primary food, Household consumption pattern, Elasticity, Price and Income.

\begin{abstract}
ABSTRAK
Penelitian ini bertujuan untuk : Menganalisis pola konsumsi pangan rumahtangga menurut tingkat pendapatan dan pendidikan, Menganalisis faktor-faktor dominan yang mempengaruhi pengeluaran konsumsi pangan pokok rumahtangga, dan Menganalisis respon pengeluaran konsumsi pangan pokok terhadap faktor-faktor dominan yang mempengaruhinya. Untuk menjawab tujuan penelitian ini dibangun model Almost Ideal Demand System (AIDS) dengan metode Seemingly Unrelated Regression (SUR). Komoditas pangan pokok yang dimasukkan dalam model mencakup tujuh komoditas meliputi: beras dan sagu, susu, daging sapi dan ayam, garam, gula pasir, minyak goreng, serta sayur-sayuran dan buah-buahan. Hasil penelitian menunjukkan bahwa semakin tinggi tingkat pendapatan, proporsi pengeluaran pangan cenderung menurun. Semakin tinggi pendidikan ibu rumah tangga semakin banyak pula konsumsi susu, daging sapi dan ayam, sayur-sayuran serta buah-buahan, sedangkan konsumsi beras dan sagu, gula pasir, dan minyak goreng cenderung menurun. Sebahagian besar estimasi parameter harga komoditas dan pendapatan rumahtangga dominan mempengaruhi tingkat konsumsi untuk setiap kelompok komoditas. Hasil elastisitas harga pada seluruh komoditas yang diamati bertanda negatif dan tidak responsif terhadap perubahan harganya. Demikian juga halnya, elastisitas silang menunjukkan pengeluaran konsumsi masing-
\end{abstract}


masing komoditas yang diamati tidak responsif terhadap perubahan harga komoditas lainnya. Sedangkan elastisitas pendapatan, terdapat dua komoditas yaitu daging sapi dan ayam, serta sayursayuran dan buah-buahan, responsif terhadap perubahan pendapatan. Dari temuan tersebut, dapat dinyatakan bahwa kebijakan yang berkaitan dengan upaya peningkatan pendapatan lebih baik dilakukan dibandingkan dengan kebijakan pengendalian harga. Upaya untuk memperbaiki pendapatan rumahtangga penting dilakukan untuk meningkatkan konsumsi masyarakat, khususnya konsumsi daging sapi dan ayam, serta sayur-sayuran dan buah-buahan.

Kata kunci: Bahan pangan pokok, Pola kosnusmsi rumah tangga, elastisitas, harga, dan pendapatan .

\section{PENDAHULUAN}

Terjaminnya ketersediaan pangan dalam jumlah yang cukup, kualitas yang memadai dan tingkat harga yang terjangkau oleh rumahtangga merupakan sasaran dan target yang ingin dicapai dalam penyusunan dan perumusan kebijakan pangan nasional. Ketidakstabilan persediaan pangan dan/atau gejolak harga pangan pokok, kekurangan beras di Indonesia telah terbukti dapat memicu munculnya gejolak nasional yang mengarah pada tindak kriminal. Ada beberapa kebijakan pemerintah yang pernah dilakukan dalam mengendalikan harga pangan, misalnya pengendalian harga beras melalui bulog, operasi pasar untuk mengendalikan minyak goreng, impor untuk mengendalikan harga gula dan terigu. Kebijakan pemerintah dalam peningkatan diversifikasi pangan juga telah dilakukan mengacu pada Peraturan Presiden Nomor 22 Tahun 2009 dan Peraturan Menteri Pertanian Nomor 43 Tahun 2009 tentang peningkatan keanekaragaman pangan sesuai karakteristik daerah sebagai acuan yang dapat mendorong percepatan penganekaragaman konsumsi pangan (P2KP) berbasis sumberdaya lokal melalui kerjasama sinergi antara pemerintah pusat dan pemerintah daerah.

Secara teoritis, permintaan terhadap suatu komoditas atau kelompok komoditas dipengaruhi oleh harga komoditas yang bersangkutan, harga komoditas lain yang memiliki hubungan dengan komoditas tersebut, tingkat pendapatan dan selera. Menurut Koutsonyianis (1979), secara konseptual permintaan merupakan suatu fungsi yang dipengaruhi oleh banyak peubah (multivariate). Peubah-peubah penting yang mempengaruhi permintaan adalah harga barang yang bersangkutan, harga barang lain, pendapatan serta selera. Menurut Ischak (2005), dalam analisis jangka pendek dapat diasumsikan tidak terdapat perubahan selera, oleh karena itu konsumsi dan permintaan suatu komoditas ditentukan oleh tingkat harga-harga dan pendapatan. Apabila harga-harga disuatu wilayah diasumsikan homogen, dapat dihipotesiskan bahwa penduduk (rumahtangga) yang memiliki tingkat pendapatan berbeda akan memiliki pola konsumsi dan permintaan yang berbeda pula. Masalah utama yang mempengaruhi permintaan dan konsumsi pangan, yaitu harga komoditas yang bersangkutan berfluktuasi dan cenderung meningkat, ketersediaan bahan makanan semakin terbatas, tingkat pendapatan dan selera masyarakat yang selalu berubah. Oleh karenanya kajian yang berkaitan dengan pola konsumsi dan faktor-faktor yang mempengaruhi pengeluaran pokok rumahtangga sangat diperlukan sebagai bagian yang tidak terpisahkan dengan upaya mewujudkan ketahanan pangan nasional.

Secara umum penelitian ini bertujuan untuk menganalisis perilaku konsumsi pangan oleh rumahtangga di Provinsi Riau. Secara spesifik bertujuan untuk : (1) Menganalisis pola konsumsi pangan rumahtangga menurut golongan pendapatan (rendah, sedang dan tinggi) dan pendidikan di Provinsi Riau, (2) Menganalisis faktor-faktor dominan yang mempengaruhi pengeluaran konsumsi pangan pokok rumahtangga, dan (3) Menganalisis respon pengeluaran konsumsi pangan pokok terhadap faktor-faktor dominan yang mempengaruhinya.

\section{METODE PENELITIAN}

\section{Jenis dan Sumber Data}

Jenis data yang digunakan dalam penelitian ini adalah data sekunder yaitu data 
Survei Sosial Ekonomi Nasional (SUSENAS) tahun 2008. Data tersebut merupakan data penampang lintang (cross section) yang bersumber dari Badan Pusat Statistik (BPS).

\section{Spesifikasi Model}

Model yang digunakan adalah aproksimasi linear dari Model Almost Ideal Demand System (AIDS) yang merupakan modifikasi dari model yang dikembangkan oleh Deaton el al., (1980). Dipilihnya model ini karena model sistem permintaan lebih mampu mengadopsi fenomena perilaku konsumen dalam mengkonsumsi suatu komoditas, dimana komoditas yang dikonsumsi rumahtangga bermacam-macam dan saling terkait satu dengan yang lainnya. Keputusan untuk mengkonsumsi suatu komoditas akan berpengaruh pada tingkat konsumsi komoditas lainnya. Modifikasi model AIDS dilakukan dengan memasukkan peubah jumlah anggota rumahtangga, tingkat pendidikan ibu rumahtangga dan golongan pendapatan rumahtangga. Model LA/AIDS tersebut diformulasikan sebagai berikut :

$W i=\alpha_{i}^{*}+\sum_{j} \gamma i j \log P j+\beta i \log \left(X / P^{*}\right)+$

dimana

$$
\theta i \mathrm{~S}+d_{1 i} D_{1}+d_{2 i} D_{2}+d_{3} D_{3} .(1)
$$

$\mathrm{i}, \mathrm{j}=1,2, \ldots, 8$, yang masing-masing menunjukkan kelompok komoditas beras dan sagu, gula pasir, sayur-sayuran dan buahbuahan, daging sapi dan ayam, minyak goreng, susu, dan garam beriodium.

Wi = Pangsa dari kelompok pangan ke-i terhadap total pengeluaran pangan $(w i=$ piqi $/ x)$.

$\alpha, \beta, \gamma, \theta,=$ Parameter regresi berturut-turut untuk intersep, pengeluaran, harga agregat, jumlah anggota keluarga, untuk masing-masing komoditas.

$\mathrm{Pj} \quad=$ Harga tertimbang kelompok pangan ke-j $\left(\mathrm{Pj}=\sum \mathrm{WkPk}\right)$.

$\mathrm{X}=$ Pengeluaran total kelompok pangan pokok.

P* = Indeks harga Stone, dimana log $\mathrm{P}^{*}=\sum$ wi log pi.

$\mathrm{S}=$ Jumlah Anggota rumah tangga.

$\mathrm{D}_{1} \quad=$ Dummy Pendidikan; $\mathrm{D}_{1}=1$ : Pendidikan tinggi; $\quad \mathrm{D}_{1}=0$ : lainnya

$\mathrm{D}_{2}=$ Dummy Pendapatan; $\mathrm{D}_{2}=1$ : Pendapatan rendah; $\mathrm{D}_{2}=0$ :
Pendapatan lainnya

$\mathrm{D}_{3} \quad=$ Dummy Pendapatan; $\mathrm{D}_{3}=1$ : Pendapatan tinggi; $\mathrm{D}_{3}=0$ : Pendapatan lainnya

\section{Prosedur Analisis Data}

\section{Metode Pendugaan Model}

Pendugaan parameter model LA/AIDS dilakukan untuk mengetahi faktor-faktor dominan yang mempengaruhinya pengeluaran konsumsi pangan pokok rumahtangga di Provinsi Riau. Metode analisis yang digunakan adalah metode Seemingly Unrelated Regression (SUR).

\section{Restriksi}

Untuk memenuhi teori permintaan, dalam pendugaan model LA/AIDS tersebut diterapkan restriksi-restriksi sebagai berikut (Henderson and Quandt. 1980, Varian, H.R 1984).:

(i) Simetri : $\gamma \mathrm{ij}=\gamma \mathrm{ji}$

(ii) Homogenitas : $\sum_{j} \gamma i j=0$

(iii) Adding-up : $\sum_{i} \alpha i=1, \quad \sum_{i} \gamma i j=0$, $\sum_{i} \beta i=0, \sum_{i} \theta i=0$, i, (4)

\section{Uji Asumsi Ekonometrik}

Agar memberikan hasil yang valid secara ekonometrik perlu dilakukan pengujian beberapa asumsi ekonometrika yang meliputi pendekteksian normalitas dan heteroskedastisitas dari setiap persamaan dalam model. Pendeteksian normalitas menggunakan Shapiro-Wilk test, dan pendeteksian masalah heteroskedastisitas menggunakan BreuschPagan test (Thomas, 1997; Verbeek et al., 2000).

\section{Perhitungan Nilai Elastisitas.}

Elastisitas harga sendiri, elastisitas harga silang dan elastisitas pendapatan di rumuskan sebagai berikut (Kahar, 2010):

1. Elastisitas harga sendiri

$$
e_{i i}=\frac{\gamma_{i j-\beta_{i} W_{i}}}{W_{i}}-1
$$

2. Elastisitas harga silang:

$$
e_{i j}=\frac{\gamma_{i j-\beta_{i} W_{i}}}{W_{i}} ;(i \neq j) \text {. }
$$

3. Elastisitas pengeluaran (pendapatan) :

$$
\eta_{i}=\frac{\beta_{i j}}{W_{i}}+1
$$




\section{HASIL DAN PEMBAHASAN}

\section{Keragaan Model}

Ada tujuh persamaan pangsa pengeluaran pangan pokok yang dianalisis dari tujuh komoditas (kelompok komoditas) pangan pokok terpilih, yaitu: beras dan sagu, susu, daging sapi dan ayam, garam, gula pasir, minyak goreng, sayur-sayuran dan buah-buahan. Terhadap pendugaan tujuh persamaan pangsa pengeluaran tersebut dilakukan uji restriksi pada beberapa parameter yang memenuhi persyaratan adding up, homogenitas dan simetris. Selain itu juga dilakukan normalitas dan uji heteroskedasitas.

Hasil estimasi terhadap tujuh persamaan tersebut menunjukkan nilai koefisien determinasi $\left(\mathrm{R}^{2}\right)$ berkisar antara 0.31435 sampai 0.6189. Hal ini mengindikasikan bahwa peubah-peubah penjelas yang dimasukan kedalam model dapat menjelaskan variasi pangsa pengeluaran komoditas pangan pokok sekitar 31.43 persen sampai 61.89 persen, sedangkan sisanya dijelaskan oleh faktor lainnya yang tidak dimasukan kedalam model.
Hasil uji normalitas dengan menggunakan Shapiro Wilk Test dan uji homoskedastisitas dengan menggunakan kebalikannya (uji heteroskedastisitas) menunjukkan bahwa Pr > ChiSq yang berbeda nyata dengan nol pada taraf 5\%. Hal ini mengindikasikan bahwa data berdistribusi normal dan tidak terjadi masalah heteroskedastisitas sehingga layak untuk dinterpretasikan.

\section{Pola Konsumsi Rumahtangga}

Hasil analisis rata-rata jumlah konsumsi pangan pokok per kapita menurut kelompok pendapatan menunjukkan bahwa semakin tinggi pendapatan jumlah konsumsi per kapita perbulan ketujuh komoditas yang dianalisis tersebut memperlihatkan semakin besar jumlah komoditas yang dikonsumsi rata-rata per kapita per bulan. Hal ini memperlihatkan bahwa semakin tinggi pendapatan menunjukkan semakin tinggi jumlah permintaan (konsumsi) untuk komoditas pangan. Hal ini mengandung pengertian bahwa rumahtangga Provinsi Riau pola konsumsinya masih untuk pemenuhan kebutuhan pangan.

$\underline{\text { Tabel 1. Rata-rata Jumlah Konsumsi Pangan Pokok Per Kapita Menurut Kelompok Pendapatan. }}$

\begin{tabular}{lccccccc}
\hline Kelompok Pendapatan & $\begin{array}{c}\text { Susu } \\
(\mathrm{Kg})\end{array}$ & $\begin{array}{c}\text { Beras } \\
\text { dan Sagu } \\
(\mathrm{Kg})\end{array}$ & $\begin{array}{c}\text { Daging } \\
\text { Sapi dan } \\
\text { Ayam } \\
(\mathrm{Kg})\end{array}$ & $\begin{array}{c}\text { Gara } \\
\mathrm{m} \\
(\mathrm{Kg})\end{array}$ & $\begin{array}{c}\text { Gula } \\
\text { Pasir } \\
(\mathrm{Kg})\end{array}$ & $\begin{array}{c}\text { Minyak } \\
\text { Goreng } \\
(\mathrm{Kg})\end{array}$ & $\begin{array}{c}\text { Sayur } \\
\text { dan Buah } \\
(\mathrm{Kg})\end{array}$ \\
\hline Rendah & 1,64 & 6,14 & 1,07 & 1,47 & 0,81 & 1,36 & 16,08 \\
Sedang & 1,98 & 7,49 & 1,45 & 1,97 & 0,97 & 1,67 & 21,22 \\
Tinggi & 2,47 & 10,57 & 1,59 & 2,28 & 1,31 & 2,24 & 23,44 \\
\hline
\end{tabular}

Sumber : Susenas, data diolah.

Hasil Rata-rata pengeluaran perkapita rumahtangga untuk komoditas terpilih menurut tingkat pendidikan Ibu rumahtangga. Konsumsi pangan sumber protein, vitamin/mineral yaitu susu dan daging sapi dan ayam, sayur-sayuran serta buah-buahan dari Ibu rumahtangga berpendidikan menengah keatas menunjukkan peningkatan kecukupan gizi yang lebih membaik dari pada Ibu rumahtangga yang berpendidikan menegah kebawah, hal ini dilihat dari besaran pengeluaran untuk konsumsi komoditas tersebut semakin tinggi tingkat pendidikan rumahtangga menunjukkan semakin tinggi pengeluaran susu, daging sapi dan ayam, sayur-sayuran serta buahbuahan. Untuk komoditas garam, gula pasir, sayur dan buah tidak terjadi perbedaan yang cukup berarti antara pendidikan menengah kebawah dan pendidikan menengah keatas. Pada pendidikan menegah kebawah komoditas beras dan sagu, dan sayur dan buah masih merupakan komoditas utama. 
Tabel 2. Rata-rata Pengeluaran Konsumsi Pangan Pokok Perkapita Per Bulan Menurut Tingkat Pendidikan Ibu Rumahtangga.

\begin{tabular}{llrrrrrr}
\hline $\begin{array}{c}\text { Kelompok } \\
\text { Pendapatan }\end{array}$ & $\begin{array}{c}\text { Susu } \\
(\mathrm{Kg})\end{array}$ & $\begin{array}{c}\text { Beras dan } \\
\text { Sagu (Kg) }\end{array}$ & $\begin{array}{c}\text { Daging Sapi } \\
\text { dan Ayam (Kg) }\end{array}$ & $\begin{array}{c}\text { Garam } \\
(\mathrm{Kg})\end{array}$ & $\begin{array}{c}\text { Gula } \\
\text { Pasir } \\
(\mathrm{Kg})\end{array}$ & $\begin{array}{c}\text { Minyak } \\
\text { Goreng } \\
(\mathrm{Ltr})\end{array}$ & $\begin{array}{c}\text { Sayur } \\
\text { dan } \\
\text { Buah } \\
(\mathrm{Kg})\end{array}$ \\
\hline Menengah ke bawah & 20,495 & 39,655 & 22,566 & 1,328 & 4,694 & 26,228 & 46,322 \\
Menengah ke atas & 22,128 & 37,870 & 27,571 & 1,328 & 4,383 & 24,968 & 47,456 \\
\hline
\end{tabular}

Sumber : Susenas, data diolah.

\section{Prilaku Konsumsi Pangan Pokok}

\section{Konsumsi Beras dan Sagu}

Peubah yang signifikan (faktor dominan) mempengaruhi konsumsi beras dan sagu rumahtangga di Provinsi Riau adalah harga beras dan sagu, harga daging sapi dan ayam, harga garam, harga minyak goreng, dan harga sayur-sayuran dan buah-buahan. Tanda dan besaran parameter dugaan berturut-turut sebesar $0.0191,-0.0038,-0.0009,-0.0065$ dan 0.0062 . Parameter dugaan harga beras dan sagu sebesar 0.0191 mengandung pengertian bahwa apabila harga beras dan sagu meningkat sebesar satu rupiah maka pengeluaran konsumsi beras dan sagu meningkat sebesar 0.0191 rupiah. Hal ini terjadi karena beras dan sagu merupakan komoditas sumber kalori utama rumahtangga di Provinsi Riau. Rumahtangga akan berusaha mempertahankan jumlah konsumsinya, sehingga apabila harga meningkat maka pengeluaran konsumsinya juga ikut meningkat. Selanjutnya tanda negatif parameter dugaan harga daging sapi dan ayam, harga garam, dan harga minyak goreng mengindikasikan bahwa komoditas beras dan sagu berkomplemen dengan ketiga komoditas (kelompok komoditas) tersebut. Sebaliknya tanda positif dari parameter harga sayur-sayuran dan buah-buahan mengindikasikan bahwa komoditas beras dan sagu bersubstitusi dengan komoditas ini.

Tabel 3. Pendugaan Parameter Pangsa Komoditas Menggunakan Metode SUR.

\begin{tabular}{lrrrrrrr}
\hline \multicolumn{1}{c}{ Variabel } & $\begin{array}{c}\text { Beras dan } \\
\text { Sagu }\end{array}$ & Susu & $\begin{array}{c}\text { Daging } \\
\text { Sapi \& } \\
\text { Ayam }\end{array}$ & Garam & Gula Pasir & $\begin{array}{r}\text { Minyak } \\
\text { Goreng }\end{array}$ & $\begin{array}{c}\text { Sayur dan } \\
\text { Buah }\end{array}$ \\
\hline Intercept & $0,2952 \mathbf{c}$ & $0,1671 \mathbf{c}$ & $-0,0543 \mathbf{c}$ & $0,0147 \mathbf{c}$ & $0,0429 \mathbf{c}$ & $0,2081 \mathbf{c}$ & $0.3264 \mathbf{c}$ \\
Harga beras dan sagu & $0,0191 \mathbf{c}$ & $-0,0005$ & $-0,0038 \mathbf{a}$ & $-0,0009 \mathbf{c}$ & $-0,0011$ & $-0,0065 \mathbf{c}$ & $-0.0062 \mathbf{b}$ \\
Harga susu & $-0,0005$ & $0,0155 \mathbf{c}$ & $-0,0021 \mathbf{b}$ & $-0,0001$ & $-0,0003$ & $-0,0034 \mathbf{c}$ & $-0.0091 \mathbf{c}$ \\
Harga daging sapi\& ayam & $-0,0038 \mathbf{a}$ & $-0,0021 \mathbf{b}$ & $0,0124 \mathbf{c}$ & $-0,0001$ & 0,0006 & 0,0011 & $-0.0082 \mathbf{c}$ \\
Harga garam & $-0,0009 \mathbf{c}$ & $-0,0001$ & $-0,0001$ & $0,0013 \mathbf{c}$ & 0 & 0 & $-0.0003 \mathbf{a}$ \\
Harga gula pasir & $-0,0011$ & $-0,0003$ & 0,0006 & $-0,0001$ & $0,0016 \mathbf{c}$ & $-0,0015 \mathbf{c}$ & 0.0007 \\
Harga minyak goring & $-0,0065 \mathbf{c}$ & $-0,0034 \mathbf{c}$ & 0,0011 & 0 & $-0,0015 \mathbf{c}$ & $0,0112 \mathbf{c}$ & -0.0015 \\
Harga Sayur dan Buah & $-0,0062 \mathbf{b}$ & $-0,0091 \mathbf{c}$ & $-0,0082 \mathbf{c}$ & $-0,0003 \mathbf{a}$ & 0,0007 & $-0,0015$ & $0.0246 \mathbf{c}$ \\
Lnp & $-0,0115 \mathbf{c}$ & $-0,0098 \mathbf{c}$ & $0,0364 \mathbf{c}$ & $-0,0008 \mathbf{c}$ & $-0,0024 \mathbf{c}$ & $-0,0143 \mathbf{c}$ & $0.0025 \mathbf{c}$ \\
Jmlh anggota rt & $-0,0478 \mathbf{c}$ & $-0,0125 \mathbf{c}$ & $-0,2489 \mathbf{c}$ & 0,0002 & $-0,0013 \mathbf{b}$ & 0,0037 & $-0.1523 \mathbf{c}$ \\
Dummy pendidikan & $-0,0153 \mathbf{c}$ & $-0,0038$ & $-0,0450 \mathbf{c}$ & 0,0002 & $-0,0005$ & $-0,0002$ & $-0.0209 \mathbf{c}$ \\
Dummy pendapatan d2 & $-0,0060 \mathbf{b}$ & 0 & $-0,0216 \mathbf{c}$ & $-0,0001$ & 0,0001 & $-0,0022$ & $-0.0211 \mathbf{c}$ \\
Dummy pendapatan d3 & $-0,0100 \mathbf{c}$ & 0,0011 & $-0,0555 \mathbf{c}$ & 0 & 0,0002 & 0,0005 & $-0.0418 \mathbf{c}$ \\
\hline
\end{tabular}

Keterangan: a Signifikan pada taraf 10 persen, b Signifikan pada taraf 5 persen, c Signigikan pada taraf 1 persen

Tabel 4. Elastisitas Harga Sendiri dan Harga Silang Beberapa Komoditas Pangan Pokok.

\begin{tabular}{lrrrrrrr}
\hline \multicolumn{1}{c}{ Komoditas } & \multicolumn{7}{c}{ Harga Komoditas } \\
\cline { 2 - 8 } & $\begin{array}{c}\text { Beras dan } \\
\text { Sagu }\end{array}$ & Susu & $\begin{array}{c}\text { Daging Sapi } \\
\text { \& Ayam }\end{array}$ & Garam & Gula Pasir & $\begin{array}{c}\text { Minyak } \\
\text { Goreng }\end{array}$ & $\begin{array}{c}\text { Sayur Sayuran } \\
\& \text { Buah- } \\
\text { buahan }\end{array}$ \\
\hline Beras dan Sagu & $-0,6824$ & $-0,0031$ & $-0,0829$ & $-0,0138$ & $-0,018$ & $-0,0948$ & $-0,1025$ \\
Susu & 0,0063 & $-0,5066$ & $-0,1054$ & $-0,0027$ & $-0,091$ & $-0,0877$ & $-0,29$ \\
Daging Sapi \& Ayam & $-0,0863$ & $-0,0484$ & $-0,6945$ & $-0,0019$ & 0,0175 & 0,048 & $-0,2303$ \\
Garam & $-0,0675$ & 0,1037 & $-0,6367$ & $-0,4052$ & 0,0054 & 0,2911 & $-0,2233$ \\
Gula Pasir & $-0,0559$ & 0,0008 & $-0,0919$ & $-0,0007$ & $-0,7813$ & $-0,1201$ & 0,069 \\
Minyak Goreng & $-0,1379$ & $-0,074$ & $-0,0043$ & 0,0008 & $-0,0358$ & $-0,7046$ & $-0,0407$ \\
Sayur \& Buah & $-0,074$ & $-0,1192$ & $-0,1281$ & $-0,004$ & 0,0099 & $-0,0124$ & $-0,6702$ \\
\hline
\end{tabular}


Tabel 5. Elastisitas Pendapatan Beberapa Komoditas Pangan Pokok.

\begin{tabular}{|c|c|}
\hline Komoditas & Elastisitas Pendapatan \\
\hline Beras dan Sagu & 0.8158 \\
\hline Susu & 0.6937 \\
\hline Daging Sapi \& Ayam & 2.0029 \\
\hline Garam & 0.6330 \\
\hline Gula Pasir & 0.6819 \\
\hline Minyak Goreng & 0.6578 \\
\hline Sayur Sayuran \& Buah-buahan & 1.0341 \\
\hline
\end{tabular}

Elasitisitas harga sendiri dan harga silang (lihat Tabel 4 dan Tabel 5) seluruhnya lebih kecil dari satu (dalam nilai absolut). Hal ini mengindikasikan bahwa pengaruh peubahpeubah tersebut tidak responsif terhadap konsumsi beras dan sagu oleh rumahtangga di Provinsi Riau. Sedangkan hasil dari perhitungan elastisitas pendapatan juga besaran nilai elastisitasnya kecil dari satu. Hal ini juga mengandung pengertian bahwa elastisitas pendapatan tidak responsif terhadap konsumsi beras dan sagu rumahtangga di Provinsi Riau.

\section{Konsumsi Susu}

Peubah yang signifikan mempengaruhi konsumsi susu rumahtangga di Provinsi Riau adalah harga susu, harga daging sapi dan ayam, harga minyak goreng, dan harga sayur-sayuran dan buah-buahan. Tanda dan besaran parameter dugaan berturut-turut sebesar $0.0155,-0.0021$, dan -0.0034. Hal ini terjadi karena susu merupakan komoditas sumber protein utama rumahtangga di Provinsi Riau. Rumahtangga akan berusaha mempertahankan jumlah konsumsinya, sehingga apabila harga meningkat maka pengeluaran konsumsinya juga ikut meningkat. Selanjutnya tanda negatif parameter dugaan harga daging sapi dan ayam, harga minyak goreng, dan harga sayur-sayuran dan buah-buahan mengindikasikan bahwa komoditas susu berkomplemen dengan ketiga komoditas tersebut. Sebaliknya tanda positif dari parameter harga sayur-sayuran dan buah-buahan mengindikasikan bahwa komoditas beras dan sagu bersubstitusi dengan komoditas ini.

Elasitisitas harga sendiri dan harga silang (lihat Tabel 4 dan Tabel 5) seluruhnya besaran nilainya lebih kecil dari satu (dalam nilai absolut), hal ini senada dengan konsumsi beras dan sagu. Hal ini mengindikasikan bahwa pengaruh peubah-peubah tersebut tidak responsif terhadap konsumsi susu oleh rumahtangga di Provinsi Riau. Sedangkan hasil perhitugan menunjukan elastisitas pendapatan juga besaran nilai elastisitasnya kecil dari satu.
Hal ini juga mengandung pengertian bahwa elastisitas pendapatan tidak responsif terhadap konsumsi susu rumahtangga di Provinsi Riau.

\section{Konsumsi Daging Sapi dan Ayam}

Peubah yang signifikan mempengaruhi konsumsi Daging Sapi dan Ayam rumahtangga di Provinsi Riau adalah harga daging sapi dan ayam, harga susu, harga beras dan sagu, dan harga sayur-sayuran dan buah-buahan. Tanda dan besaran parameter dugaan berturut-turut sebesar $0.0124,-0.021,-0.0038$, dan -0.0082 . Hal ini terjadi karena susu merupakan komoditas sumber protein rumahtangga di Provinsi Riau. Rumahtangga akan berusaha mempertahankan jumlah konsumsinya, sehingga apabila harga meningkat maka pengeluaran konsumsinya juga ikut meningkat. Selanjutnya tanda negatif parameter dugaan harga susu, harga beras dan sagu, dan harga sayur-sayuran dan buah-buahan mengindikasikan bahwa komoditas daging sapi dan ayam berkomplemen dengan ketiga komoditas tersebut. Sebaliknya tanda positif dari parameter harga sayur-sayuran dan buah-buahan mengindikasikan bahwa komoditas beras dan sagu bersubstitusi dengan komoditas ini.

Elasitisitas harga sendiri dan harga silang (lihat Tabel 4 dan Tabel 5) seluruhnya besaran nilainya lebih kecil dari satu (dalam nilai absolut), hal ini senada dengan konsumsi beras dan sagu dan susu. Hal ini mengindikasikan bahwa pengaruh peubah-peubah tersebut tidak responsif terhadap konsumsi daging sapi dan ayam oleh rumahtangga di Provinsi Riau. Sedangkan elastisitas pendapatan dari hasil perhitungan besaran nilai elastisitasnya besar dari satu. Hal ini juga mengandung pengertian bahwa elastisitas pendapatan responsif terhadap konsumsi daging sapi dan ayam rumahtangga di Provinsi Riau. 


\section{Konsumsi Garam}

Peubah yang signifikan mempengaruhi konsumsi garam rumahtangga di Provinsi Riau adalah harga garam, harga beras dan sagu, dan harga sayur -sayuran dan buah-buahan. Tanda dan besaran parameter dugaan berturut-turut sebesar $0.0013,-0.0009$, dan -0.0003 . Hal ini terjadi karena garam merupakan komoditas sumber kebutuhan utama garam beriodium rumahtangga di Provinsi Riau. Rumahtangga akan berusaha mempertahankan jumlah konsumsinya, sehingga apabila harga meningkat maka pengeluaran konsumsinya juga ikut meningkat. Selanjutnya tanda negatif parameter dugaan harga beras dan sagu, dan harga sayur sayuran dan buah-buahan. mengindikasikan bahwa komoditas garam berkomplemen dengan kedua komoditas (kelompok komoditas) tersebut. Sebaliknya tanda positif dari parameter harga sayur-sayuran dan buah-buahan mengindikasikan bahwa komoditas beras dan sagu bersubstitusi dengan komoditas ini.

Elasitisitas harga sendiri dan harga silang (lihat Tabel 4 dan Tabel 5) seluruhnya besaran nilainya lebih kecil dari satu (dalam nilai absolut), hal ini senada dengan konsumsi beras dan sagu, konsumsi susu, dan konsumsi daging sapi dan ayam. Hal ini mengindikasikan bahwa pengaruh peubah-peubah tersebut tidak responsif terhadap konsumsi garam oleh rumahtangga di Provinsi Riau. Sedangkan hasil perhitugan menunjukan elastisitas pendapatan juga besaran nilai elastisitasnya kecil dari satu hal ini senada dengan elastisitas pendapatan beras dan sagu dan susu. Hal ini juga mengandung pengertian bahwa elastisitas pendapatan tidak responsif terhadap konsumsi garam rumahtangga di Provinsi Riau.

\section{Konsumsi Gula Pasir}

Peubah yang signifikan mempengaruhi konsumsi gula pasir rumahtangga di Provinsi Riau adalah harga gula pasir dan harga minyak goreng. Tanda dan besaran parameter dugaan berturut-turut sebesar 0.0016, dan -0.0015. Hal ini terjadi karena gula pasir merupakan komoditas kebutuhan pokok rumahtangga di Provinsi Riau. Rumahtangga akan berusaha mempertahankan jumlah konsumsinya, sehingga apabila harga meningkat maka pengeluaran konsumsinya juga ikut meningkat. Selanjutnya tanda negatif parameter dugaan harga minyak goreng. Hal ini mengindikasikan bahwa komoditas gula pasir berkomplemen dengan komoditas minyak goreng (kelompok komoditas) tersebut. Sebaliknya tanda positif dari parameter harga sayur-sayuran dan buahbuahan mengindikasikan bahwa komoditas beras dan sagu bersubstitusi dengan komoditas ini.

Elasitisitas harga sendiri dan harga silang (lihat Tabel 4 dan Tabel 5) seluruhnya besaran nilainya lebih kecil dari satu (dalam nilai absolut. Hal ini mengindikasikan bahwa pengaruh peubah-peubah tersebut tidak responsif terhadap konsumsi gula pasir oleh rumahtangga di Provinsi Riau. Sedangkan hasil perhitugan menunjukan elastisitas pendapatan juga besaran nilai elastisitasnya kecil dari satu. Hal ini juga mengandung pengertian bahwa elastisitas pendapatan tidak responsif terhadap konsumsi gula pasir rumahtangga di Provinsi Riau.

\section{Konsumsi Minyak Goreng}

Peubah yang signifikan (faktor dominan) mempengaruhi konsumsi minyak goreng rumahtangga di Provinsi Riau adalah harga minyak goreng, harga susu, harga beras dan sagu, dan gula pasir. Tanda dan besaran parameter dugaan berturut-turut sebesar 0.0118, $-0.0034,-0.0065$, dan -0.0015 . Hal ini terjadi karena minyak goreng merupakan komoditas kebutuhan pokok rumahtangga di Provinsi Riau. Rumahtangga akan berusaha mempertahankan jumlah konsumsinya, sehingga apabila harga meningkat maka pengeluaran konsumsinya juga ikut meningkat. Selanjutnya tanda negatif parameter dugaan harga susu, harga beras dan sagu, dan gula pasir. Hal ini mengindikasikan bahwa komoditas minyak goreng berkomplemen dengan ketiga komoditas (kelompok komoditas) tersebut. Sebaliknya tanda positif dari parameter harga sayur-sayuran dan buah-buahan mengindikasikan bahwa komoditas beras dan sagu bersubstitusi dengan komoditas ini

Elasitisitas harga sendiri dan harga silang (lihat Tabel 4 dan Tabel 5) seluruhnya besaran nilainya lebih kecil dari satu (dalam nilai absolut). Hal ini mengindikasikan bahwa pengaruh peubah-peubah tersebut tidak responsif terhadap konsumsi minyak goreng oleh rumahtangga di Provinsi Riau. Sedangkan hasil perhitugan menunjukan elastisitas pendapatan juga besaran nilai elastisitasnya kecil dari satu. Hal ini juga mengandung pengertian bahwa elastisitas pendapatan tidak 
responsif terhadap konsumsi minyak goreng rumahtangga di Provinsi Riau.

\section{Konsumsi Sayur-sayuran dan Buah- Buahan}

Peubah yang signifikan (faktor dominan) mempengaruhi konsumsi sayur-sayuran dan buah-buahan rumahtangga di Provinsi Riau adalah harga sayur-sayuran dan buah-buahan harga susu, harga beras dan sagu, harga daging sapi dan ayam, dan harga garam. Tanda dan besaran parameter dugaan berturut-turut sebesar $0.0246,-0.0091,-0.0062$, dan -0.0003 . Hal ini terjadi karena sayu-sayur dan buah-buahan merupakan komoditas kebutuhan sumber vitamin dan mineral rumahtangga di Provinsi Riau. Rumahtangga akan berusaha mempertahankan jumlah konsumsinya, sehingga apabila harga meningkat maka pengeluaran konsumsinya juga ikut meningkat. Selanjutnya tanda negatif parameter dugaan harga susu, harga beras dan sagu, harga daging sapi dan ayam, dan harga garam Hal ini mengindikasikan bahwa komoditas harga sayur-sayuran dan buahbuahan berkomplemen dengan keempat komoditas (kelompok komoditas) tersebut. Sebaliknya tanda positif dari parameter harga sayur-sayuran dan buah-buahan mengindikasikan bahwa komoditas beras dan sagu bersubstitusi dengan komoditas ini

Elasitisitas harga sendiri dan harga silang (lihat Tabel 4 dan Tabel 5) seluruhnya besaran nilainya lebih kecil dari satu (dalam nilai absolut). Hal ini mengindikasikan bahwa pengaruh peubah-peubah tersebut tidak responsif terhadap konsumsi sayur-sayuran dan buah-buahan oleh rumahtangga di Provinsi Riau. Sedangkan elastisitas pendapatan dari hasil perhitungan besaran nilai elastisitasnya besar dari satu. Hal ini juga mengandung pengertian bahwa elastisitas pendapatan responsif terhadap konsumsi daging sapi dan ayam rumahtangga di Provinsi Riau.

\section{KESIMPULAN}

Hasil penelitian menunjukkan bahwa semakin tinggi tingkat pendapatan, proporsi pengeluaran pangan cenderung menurun. Semakin tinggi pendidikan ibu rumah tangga semakin banyak pula konsumsi susu, daging sapi dan ayam, sayur-sayuran serta buahbuahan, sedangkan konsumsi beras dan sagu, gula pasir, dan minyak goreng cenderung menurun. Faktor-faktor dominan yang mempengaruhi perilaku konsumsi pangan pokok oleh rumahtangga di Provinsi Riau bervariasi untuk setiap komoditas yang diamati. Pertama, pengeluaran konsumsi beras dan sagu dominan dipengaruhi oleh harganya sendiri, harga daging sapi dan ayam, harga garam, harga minyak goreng, dan harga sayur-sayuran dan buahbuahan. Kedua, pengeluaran konsumsi susu dominan dipengaruhi oleh harga susu, harga daging sapi dan ayam, harga minyak goreng, dan harga sayur-sayuran dan buah-buahan. Ketiga, pengeluran konsumsi daging sapi dan ayam dominan dipengaruhi oleh harganya sediri, harga susu, harga beras dan sagu, dan harga sayur-sayuran dan buah-buahan. Keempat, pengeluaran konsumsi garam dominan dipengaruhi oleh harganya sendiri, harga beras dan sagu, dan harga sayur-sayuran dan buahbuahan. Kelima, pengeluaran konsumsi gula pasir dominan dipengaruhi oleh harganya sendiri, dan harga minyak goreng. Keenam, pengeluaran konumsi minyak goreng dominan dipengaruhi oleh harganya sendiri, harga susu, harga beras dan sagu, dan harga gula pasir. Dan ketujuh, pengeluaran konsumsi sayur-sayuran dan buah-buahan dominan dipengaruhi oleh harganya sendiri, harga susu, harga beras dan sagu, harga daging sapi dan ayam, dan harga garam.

Berdasarkan hasil perhitungan elastisitas dapat dinyatakan bahwa elastisitas harga sendiri untuk seluruh komoditas yang diamati bertanda negatif dengan nilai lebih kecil dari satu. Hal ini mengindikasikan bahwa pengeluaran konsumsi tujuh komoditas (kelompok komoditas) tersebut tidak responsif terhadap perubahan harganya sendiri. Demikian juga halnya dengan elastisitas harga silang menunjukkan nilai elastisitas (dalam nilai absolut) yang lebih kecil dari satu, berarti pengeluaran konsumsi masing-masing komoditas yang diamati tidak responsif terhadap perubahan harga komoditas lainnya. Sementara itu, elastisitas pendapatan menunjukkan dua komoditas yang memiliki nilai elastisitas pendapatan yang lebih besar dari 1, yaitu elastisitas pendapatan untuk daging sapi dan ayam, serta elastisitas pendapatan untuk sayursayuran dan buah-buahan. Dengan kata lain, pengeluaran konsumsi daging sapi dan ayam, serta sayur-sayuran dan buah-buahan, responsif terhadap perubahan pendapatan.

Dari temuan tersebut dapat dinyatakan bahwa kebijakan yang berkaitan dengan upaya peningkatan pendapatan lebih baik dilakukan 
dibandingkan dengan kebijakan pengendalian harga. Upaya untuk meningkatkan pendapatan rumhatangga perlu dilakukan untuk meningkatkan konsumsi masyarakat, khususnya konsumsi daging sapi dan ayam, serta sayursayuran dan buah-buahan.

\section{DAFTAR PUSTAKA}

Deaton, M. dan J. Muellbauer. 1980. An Almost Ideal Demand System. American Economic Review 70(3):312-326. American.

Henderson, J.M. and R.E. Quandt. 1980. Mocroeconomic Theory. A. mathematical approach. Third Edition, International Stident Edition. Mc. Graw Hill. Kogakusha, Ltd. Tokyo.

Ischak, P.Lumbantobing. 2005. Analisis Permintaan dan Pola Konsumsi Pangan Di Provinsi Jambi. Tesis Magister Sains. Program Pascasarjana, Institut Pertanian Bogor. Bogor.

Kahar, M. 2010. Analisis Pola Konsumsi Daerah Perkotaan dan Perdesaan Serta Keterkaitan Dengan Karakteristik Sosial Ekonomi Di Provinsi Banten. Tesis Magister Sains. Program Pascasarjana, Institut Pertanian Bogor. Bogor.

Koutsoyianis, A. $1979 . \quad$ Modern Microeconomics. $2^{\text {nd }}$ Edition. The Macmillan Press Ltd. London.

Thomas, R.L. 1997. Modern Econometrics an Introduction. Addison Wesley Longman, Harlow.

Verbeek, M., KU Leuven, and Tilburg University. 2000. A Guide to Modern Econometrics. John Wiley \& Sons Ltd., Chichester.

Varian, H.R 1984. Macroeconomic Analysis. 2 Edition. W.W. Norton and Company, New York. 
